\title{
E.U.'s Strategy of Building a Knowledge Economy
}

Roxana Mironescu, Ph.d., senior lecturer, „Vasile Alecsandri” University of Bacau, Romania Andreea Feraru, Ph.d student, assist. „Vasile Alecsandri” University of Bacau, Romania

\begin{abstract}
The European Union strategy for building knowledge-based economy includes a set of objectives, priority action areas, targets and measures to guide European policy for growth and employment. The European Union strategic objective is to become the most competitive and dynamic knowledge-based economy.

In many fields of activity, economic too, knowledge is an important source of power, or, in other words, one of the main instruments of economic and social success.

Knowledge must always be associated with mastering and anticipating changing phenomena and to the everywhere challenges.
\end{abstract}

\section{Keywords}

economy, knowledge, growth, stability, cohesion

JEL Codes: F15, F50, 010

\section{Introduction}

Due to the massive development registered in the informatic services sector the global economic landscape is fundamentally changing. There were made some major changes because of the introduction of worldwide PC, of the software technology and of the rapid development of data networks and Internet-based services. At the present it looks increasingly obvious that the world passes through a continuos rapid transition from an economy based on industry to a knowledge-based one.

It can be argued that the resulting knowledge and more knowledge. Knowledge is a public property. Once being discovered, it becomes virtually free of charge for all (excepting the knowledge protected by law). The benefits of the new discoveries will be for the benefit of everyone, sooner or later. It should be noted some important aspects of the new economy as being fundamentally different from those of the old economy, meaning that the economic laws were not changed, but the economy has changed in a radical way. In the industrial economy the capital is more important than the land. In the new economy, innovation through knowledge is the most important, it underlies many aspects of the economy. In the global knowledge economy, which is promoted, supported advantage of nations will not come from natural resources owned or on cheap labor forces, but in their ability to harness the intellectual capital. Today and tomorrow, the "mind" and not "muscle" will be important for the economic growth.

The development of civilization, the knowledge-based economy can be regarded as a further step, which presents favourable prospects of a new better way of life. This economy has an economic and also a social important impact, it is based on the use of information in all the spheres of the human existence and activity . 


\section{Defining the knowledge economy}

The time evolution for the concept of the knowledge-based economy has led to certain investigations which have established some fundamentals, as follows:

- Industry of knowledge, which will note that the future will support those industries based on knowledge, innovation, on the development of the design activities;

- A second approach which processed the knowledge economy was the Knowledge

Management approach. The first specific international conference and exhibition was held in Brussels on 20- 22 December 2000. The emblem of the conference was "Europe's future is the knowledge economy" and was highlighted by Robert Taylor and Unisys.

Knowledge economy has to satisfy a maximum of determined needs with limited resources, therefore we can say this is an efficient economy. Knowledge economy is a new concept, a new kind of economy. This new economy is a gate that Professor Joseph E. Stiglitz, Nobel Prize in Economics in 2001, considers as having a "greater chance for democracy and sustained economic growth which will bring, in the near future, prosperity and social justice."

Defining the knowledge economy may be a difficult goal. First, we must consider the wide variety of successful implementation of the concept, and secondly, the specific of the various worldwide countries which registered and recognized significant progresses such as USA, Britain, France, Germany, Finland, Austria, Singapore or South Korea.

During the preparations for a knowledge-based economy, an important factor may be the recommendations elaborated by the World Bank Institute and OECD in a country study published in 2000. It was entitled "Korea and the Knowledge-Based Economy: Making the Transition" where there are presented some lines of action for the transition towards a knowledge-based economy. For example we can remember:

$>$ Strengthening intellectual property rights, promoting exploitation of intangible assets;

$>$ Take the necessary political measures to encourage competition (competitive firms are more oriented to innovation);

$>$ Managerial and curricular reform in higher education;

$>$ Encourage greater interrelationships between firms, universities and government research programs;

$>$ The proper allocation of the resources to the universities.

The European's Union efforts should be drived up to build the knowledge society, and to the continuous improvement of the administrative capacity. They are absolutely necessary priorities to support and diversify the labor market.

Only a better exploitation of the local and regional potential by strengthening local and regional powers can lead to both a sustainable development of communities, as well as by a coherent sectorial policy and change, they look feasible because of strengthening the trade relationships and the inter- and regional changes.

\section{E.U.’s Strategy}

European Union strategy for building the knowledge-based economy was adopted while the Lisbon summit in 2000.Lisbon is known as the Lisbon Agenda or Lisbon Process, and it was adopted by all the caountries participating to the Lisbon meeting, at the European Council in March 2000, for a period of 10 years. Its fundamental aim is to make Europe the "most dynamic and competitive world economy." The strategy addresses to all EU Member States and has the following main objective:

- To offset low productivity;

- To contribute to economic growth in the European Union. The main covered fields of activity there are: to support and to restore the economic life, the social life and the 
environmental protection. The Lisbon Strategy reforms enriche the five areas as shown in Figure no 1.

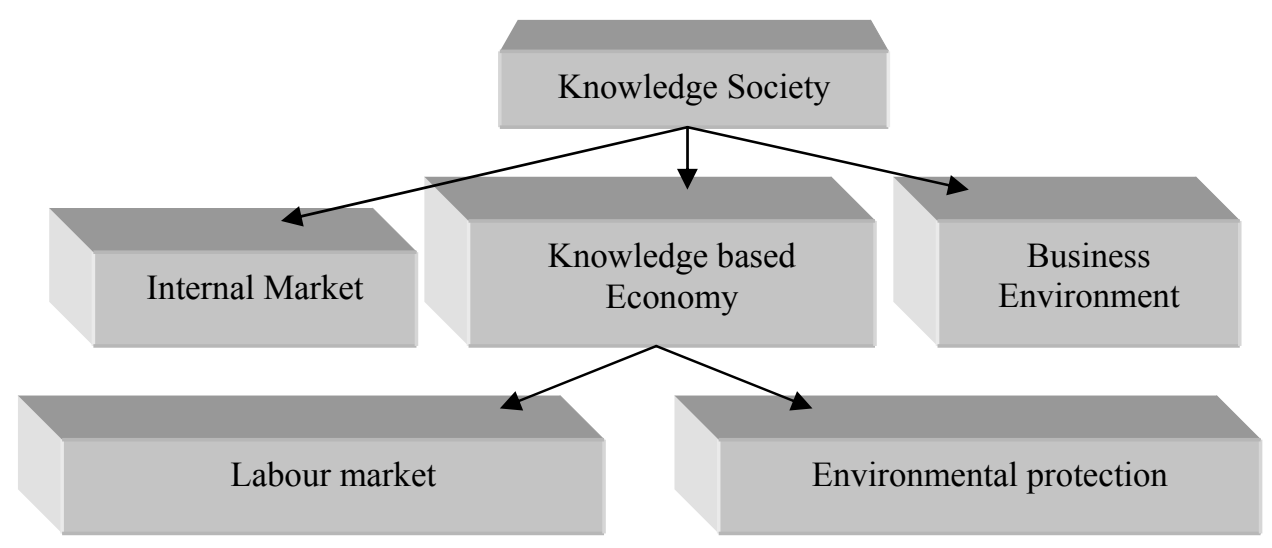

Fig. no.1. the components of a knowledge based economy.

These industries, regarding the European Union strategy for building knowledge-based economy there are:

The Knowledge Society.

Regarding knowledge in education, research, development and innovation, the document recommends measures leading to the "fifth freedom", namely the free movement of knowledge. Therefore, it would create a genuine European Research Area and an integrated patent jurisdiction, with a single affordable patent. The member countries are required to develop national strategies on implementing and internet usage in all the schools by 2010 .

$>$ The Internal Market.

Since the internal European market still has not quite managed to encourage growth, innovation and competitiveness, then, this strategy aims to action in the following areas:

- public aquirements, especially in the border areas ;

- commercial transactions involving excessive costs, especially those connected to the

intellectual property protection ;

- border barriers for services within EU;

- energy and aviation markets, which are not completed at European level.

$>$ The Business Environment.

Regarding business, the report calls for an integrated policy approach as an European law on the establishment and development of a large number of SMEs because they create nine out of ten new jobs.

$>$ The Labour market.

On this topic, the report aims to develop action plans that include a number of goals such as:

- To reduce school drop in primary and secondary forms of education;

- To invest in professional development of human resources;

- To encourage the free movement of labor;

- To modernize the labor market in the EU area.

$>$ Regarding the environment protection, the report states:

- To provide and maintain life in all its diversity, protecting the earth capacity;

- To appreciate the limited resources of the planet's natural;

- Ensure a high level of protection and improvement of environmental quality;

- To prevent and reduce environmental pollution;

- To eliminate all factors leading to environmental degradation.

The implementation of the Lisbon Strategy has updated three cycles:

- March 2000 - March 2005; 
- March 2005 - March 2008;

- March 2008 - March 2011.

During the special meeting on 23-24 March 2000 in Lisbon, the Extraordinary European Council of the European Commission received the polical initiative entitled "e-Europe - An Informatic Society for All". This is a guarantee for the EU to fully benefit, for future generations, of the developments related to informatic society. It was adopted as an Action Plan (Feira, 2000), and then was updated in 2002 in Seville by the strategic document "eEurope 2005 - An Information Society for All.

The European Commission has taken this initiative to speed up implementation of digital technologies in Europe, and to provide the necessary skills for widespread use, too.

The implementation of the Lisbon Strategy requires governmental measures in order to use the following tools:

- the Integrated Guidelines for Growth and Jobs;

- the Community Lisbon Programme;

- The Commission's annual reports on its implementation;

- The National Reform Programmes and the annual national reports on implementation of National Reform Programmes.

The member States contribute to the Lisbon National Reform Programmes and the Commission through the Community Lisbon Programme.

\section{The importance of the European Union strategy for building the knowledge- based economy in Romania}

Once the EU's access, Romania has become a part of the integration process, strengthening the European cohesion and an important player in achieving the common objectives of the Lisbon Strategy and sustainable development.

Lisbon Strategy is an opportunity for each Member State, Romania and hence, to overcome the economic difficulties of the moment, implementing structural reform measures in the economy. With the strategy review, in 2005, it was agreed that each Member State to develop a National Plan of Reforms, so that Romania fulfilled in 2007, resulting in the National Reform Plan 2007-2010 which aimed at achieving economic performance and Featured Employment of Lisbon, in conjunction with a fair social system elements to ensure sustainable development of our country.

Concerned about the achievement the objectives of the initiative "e-Europe, the EU seeks new associated countries of Central and Eastern Europe, including Romania, to achieve the objectives set by the strategic document" e-Europe 2005 - An Information Society for All. In full compliance with the lines of the Commission's proposals for Competitiveness and Innovation Framework 2007-2013, the priorities of Romania's competitiveness strategy are:

1. Improving access from this site to market, capital, technology enterprises, especially for the small and medium sized enterprises;

2. Develop knowledge based economy: including promoting innovation and development of a competitive business background;

3. Improve the power system's efficiency and encourage the renewable energy exploitation.

These priorities take into account the guidelines proposed by the Commission for Cohesion Policy 2007-2013. Thus, Romania's priorities were confirmed by the Commission which expressed its intention to support the following processes:

- Improving the access to financing for all the firms;

- Increase and improve investment in research and development;

- Facilitating innovation;

- Promoting the informatic society;

- Problem solving for the intensive traditional sources of energy in Europe. 
If we take into account all the measures that Romania must implement under the Lisbon Strategy it is necessary just to note that those measures needed to be taken in the current economic crisis. They must be an essential component of the crisis response mechanism. It requires improving the efficiency of the central and of the local government, the fiscal policy change especially limiting excessive costs and expenses and implementing a medium term financial framework (multi-annual budgetary programming). The budgetary resources must be directed to those areas that provide growth.

The crisis programmes are particularly important, there are those which measure and aim to ensure the quality of education and training system's correlation. They, in turn, must be related to the labour market needs.

\section{Conclusions}

Knowledge-based economy offers a new vision. This involves the intertwining of all the aspects of information, economic, managerial, social and technological approaches.

Implementing the new vision at local levelmujst be of a strong originality, the interdisciplinary approach is evident.

The success of knowledge-based economy requires innovation and creativity, qualities that are especially promoted by the higher education system. Entrepreneuship and leadership development is to include, according to various studies, in the academic training.

It is considered that the knowledge economy will provide a huge advantage for the emergent markets, for the isolated parts of the world economies, or for the countries like Romania.

The strategy adopted in this paper contains the role of knowledge, believed to be of the most importance in creating added value in the knowledge based economy and it is explained by highlighting a range of practices and recognized as defining elements.

Among these elements, the most important changes are the following:

$>$ the orientation of the intellectual capital from business as the main source of competitive advantage, that capital often exceeding the value of the classical assets;

$>$ the increasing share of ,information" and "knowledge"among the employees, information becoming more and more a public asset, in all the social fields.

$>$ the increasing role of information and communication technology (ICT) as a catalyzing factor for knowledge-based economy through its ability to facilitate the active dissemination of knowledge and for the accumulation of knowledge in the products and services marketing.

\section{Bibliography}

1. Apetroae, M. (2002), Către o economie bazată pe cunoaştere, UEFISCSU, Bucureşti, p. $1-5$;

2. Drucker, P.,(1999) Knowledge Management in California, Management Review, vol. 41, nr. 2/1999;

3. Dumitrescu, M. (2001), Strategii şi management strategic, Ed. Economică, Bucureşti;

4. Fox, T., Ward, H., Howard, B. (2002), Public Sector Roles in strenghthening corporate social responsibility, A baseline study, World Bank, October, p. 1-5;

5. Kelleher, D., Levene, S. (2001), Knowledge Management: A Guide to Good Practice, PWC, NewYork;

6. Kim, C., Manborgue, R.,(2003), Fair Process: Managing in Knowledge Economy, Rev. Motivation People, Nr. 1/2003;

7. Matmati, M.,(2004), Les effets sociaux des TIC et NFO et leurs liens avec la responsabilite sociale de l'Entreprise, La Revue Technologique, vol. IV, nr. 1/2004, p. 97 119 ; 
8. Nicolescu, O., Nicolescu, L.(2005), Economia, firma şi managementul bazate pe cunostinţe", Ed. Economică, Bucureşti;

9. Russu, C., Dumitrescu, M., Pleşoianu, G. (2008), Calitatea managementului firmei. Evaluare şi interpretare., Ed. Economică, Bucureşti;

10. http://www.inforegio.ro/index.php?page=JARGON;

11. http://strategia.ncsd.ro/dbimg/27_fisiere_fisier.pdf;

12.http://www.europeana.ro/stiri/. 